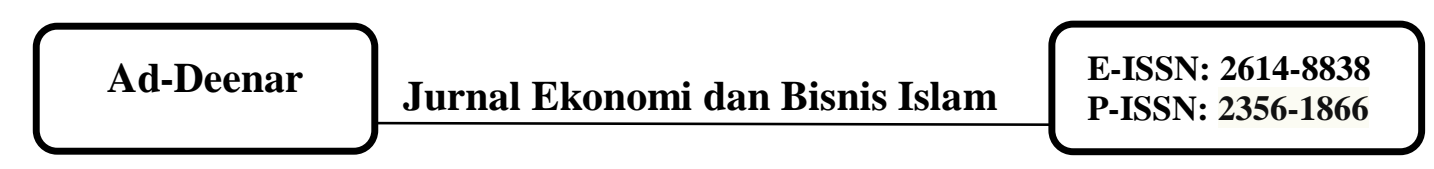

\title{
ANALISIS PRAKTIK PARIWISATA SYARIAH PERSPEKTIF HUKUM EKONOMI SYARIAH
}

\begin{abstract}
Abdurahman Misno
Prodi Ekonomi Syariah Universitas Ibn Khaldun Bogor

drmisnomei@gmail.com

\section{ABSTRAK}

Undang-Undang Nomor 10 Tahun 2009 tentang Kepariwisataan Pasal 5 Butir a menyebutkan, "Kepariwisataan diselenggarakan dengan prinsip menjunjung tinggi norma agama dan nilai budaya sebagai pengejawantahan dari konsep hidup dalam keseimbangan hubungan antara manusia dan Tuhan Yang Maha Esa, hubungan antara manusia dan sesama manusia, dan hubungan antara manusia dan lingkungan”. Berdasarkan pasal ini, maka kebijakan pengembangan pariwisata di Indonesia harus didasarkan pada nilai-nilai agama. Islam sebagai agama mayoritas di Indonesia secara otomatis menjadi pertimbangan kuat dalam pelaksanaan pariwisata syariah di Indonesia. Data dikumpulkan melalui penelusuran variable pariwisata syariah dalam perundang-undangan di Indonesia. Data analisis menggunakan teori maqashid yang diambil dari kitab Al-Mustasyfa karya Imam Al-Ghazali dan hikmatu tasyri' wa falsafatuhu karya Al-Jurjawi. Hasil penelitian menunjukkan bahwa eksistensi pariwisata syariah dalam Islam hukumnya mubah, ia akan berubah mengikuti kebutuham masing-masing manusia. Pariwisata syariah dalam perundang-undangan di Indonesia menjadi satu produk baru dengan landasan undangundang Nomor 10 Tahun 2009, dan Peraturan Menteri Pariwisata Republik Indonesia Nomor 1 Tahun 2016 tentang Penyelenggaraan Sertifikasi Usaha Pariwisata. Analisa maqashid syariah menunjukan bahwa pariwisata syariah termasuk dalam kebutuhan haajiah sehingga hukumnya boleh untuk dilakukan. Analisis maqashid Imam Al-Ghazali menunjukkan bahwa pelaksanaannya harus memperhatikan; hifdz ad-din, hifdz al-'aql, hifdz an-nafs, hifdz al-nasb dan hifdz al-maal. Analisis Maqashid Al-Jurjawi menunjukkan bahwa pariwisata syariah; mengenal Allah, sarna ibadah, amar ma'ruf nahi munkar dan tidak menghalangi pelaksanaan hukum Islam.
\end{abstract}

Keyword: pariwisata syariah, maqashid asy-syariah, mashlahah.

\section{ABSTRACT}

Law Number 10 of 2009 concerning Tourism Article 5 Point a states, "Tourism is held by the principle of upholding religious norms and cultural values as the embodiment of the concept of life in the balance of relations between man and God Almighty, the relationship between humans and fellow humans, and the relationship between humans and the environment ". Based on this article, the policy of developing tourism in Indonesia must be based on religious values. Islam as the majority religion in Indonesia automatically becomes a strong consideration in the implementation of sharia tourism in Indonesia. Data is collected through a variable search of Islamic tourism in Indonesian legislation. Data analysis uses the maqashid theory taken from the book Al-Mustasyfa by Imam Al-Ghazali and hikmatu tasyri 'wa falsafatuhu by Al-Jurjawi. The results of the study indicate that the existence of Islamic tourism in Islam is legally legal, it will change according to 
the needs of each human being. Sharia tourism in legislation in Indonesia is a new product with the foundation of law Number 10 of 2009, and Minister of Tourism Regulation of the Republic of Indonesia Number 1 of 2016 concerning Implementation of Tourism Business Certification. Analysis of Maqashid Sharia shows that Islamic tourism is included in the needs of the world so that the law is permissible. The analysis of Maqashid Imam Al-Ghazali shows that its implementation must pay attention; hifdz ad-din, hifdz al-'aql, hifdz an-nafs, hifdz al-nasb and hifdz al-maal. The analysis of Maqashid Al-Jurjawi shows that sharia tourism; know God, the same worship, amar ma'ruf nahi munkar and do not hinder the implementation of Islamic law.

\section{A. PEndahuluan}

Undang-Undang Nomor 10 Tahun 2009 tentang Kepariwisataan pasal 5 butir a menyebutkan,

"Kepariwisataan diselenggarakan dengan prinsip menjunjung tinggi norma agama dan nilai budaya sebagai pengejawantahan dari konsep hidup dalam keseimbangan hubungan antara manusia dan Tuhan Yang Maha Esa, hubungan antara manusia dan sesama manusia, dan hubungan antara manusia dan lingkungan”. Berdasarkan pasal ini maka kebijakan dalam penyelenggaraandan pengembangan pariwisata di Indonesia harus didasarkan pada nilai-nilai agama dan adat-istiadat setempat.

Indonesia sebagai negara dengan penduduk mayoritas beragama Islam memiliki kekayaan tradisi dan adat-istiadat yang tidak bisa dipisahkan dari agamanya. Tradisidan budaya yang ada di masyarakat saat ini adalah manifestasi dari agama dan kepercayaannya. Sehingga saat ini tidak bisa lagi dipisahkan antara adat-istiadat atau budaya dengan agama, keduanya telah melebur dalam satu kesatuan yaitu tradisi di masyarakat Indonesia. ${ }^{1}$

Berangkat dari fenomena inilah maka obyek wisata dalam bentuk budaya di Indonesia pada umumnya adalah bagian dari agama Islam yang telah menjadi kebanggaan masyarakat Indonesia. Sehingga apabila budaya tersebut akan dijadikan obyek wisata maka mau tidak mau harus mempertimbangkan agama masyarakatnya yaitu Islam. Sebagai agama mayoritas masyarakat Indonesia maka Islam menjadi kepercayaan dan bagian kehidupan masyarakat Indonesia.

Kekayaan tradisi, budaya, agama dan adat-istiadat masyarakat Muslim Indonesia inilah yang melatar belakangi munculnya Program Wisata Syariah oleh pemerintah Republik Indonesia melalui Kementerian

1 http://bps.go.id/download_file/Penduduk_Ind nesia_menurut_desa_SP2010.pdf. 
Pariwisata dan Ekonomi Kreatif (Kemenparekraf). ${ }^{2}$

Alasan utama dikembangkannya program ini adalah Skarena meningkatnya minat masyarakat lokal dan internasional terhadap layanan wisata berbasis syariah Islam. ${ }^{3}$ Kemenparekraf mencatat bahwa kunjungan wisatawan Muslim ke Indonesia saat ini mencapai 1.270 .437 orang per tahun yang antara lain berasal dari Arab Saudi, Bahrain, Malaysia, dan Singapura. Seperti juga negara-negara lain di dunia, produk dan pelayanan wisata dengan nilainilai syariah ini diminati oleh wisatawan muslim yang populasinya mencapai 1,8 milyar atau $28 \%$ total populasi dunia.

Wisatawan Muslim berkontribusi sekitar US\$ 126 miliar pada tahun 2011, dan diperkirakan pada tahun 2020 mereka akan membelanjakan US\$ 192 miliar untuk kebutuhan wisata mereka. Jumlah ini merupakan $13,4 \%$ dari pengeluaran wisatawan global, dan akan terus meningkat pada tahun-tahuun berikutnya. Pada delapan tahun ke depan diproyeksikan pertumbuhannya mencapai $4,8 \%$ per tahun,

\footnotetext{
${ }^{2}$ Kementerian Pariwisata dan Ekonomi Kreatif. Undang-Undang Republik Indonesia No. 10 Tahun 2009 tentang Kepariwisataan.

${ }^{3}$ http://www.budpar.go.id/asp/detil.asp?c=16\& id $=2042$.
}

sementara wisman global diproyeksikan pertumbuhannya $3,8 \%$. Saat ini $50 \%$ dari penduduk muslim di dunia berjumlah 1,8 miliar dan berada di usia kurang dari 25 tahun. Ini berarti mereka berada pada usia produktif dan memiliki potensi besar untuk bepergian menjadi wisman. ${ }^{4}$

Berdasarkan penelitian yang dilakukan oleh Master Card \& Crescent Rating tentang "Global Muslim Travel Index 2015', tersaji data bahwa di tahun 2014 terdapat 108 juta Muslim yang telah melakukan perjalanan dengan menghabiskan biaya U\$145 milyar. Angka ini merepresentasikan sekitar $10 \%$ dari total ekonomi wisata global. Pada tahun 2020 para wisatawan Muslim diprediksi akan meningkat menjadi 150 juta dengan biaya yang dikeluarkan sebesar U\$200 milyar. Ke depan, wisatawan Muslim akan terus meningkat dan menjadi salah satu sektor pariwisata yang berkembang pesat di dunia.

Selain itu populasi Muslim di dunia terus berkembang dengan pesat. Pada tahun 2030 populasi Muslim diprediksi mewakili $26,5 \%$ populasi dunia. Mayoritas populasi

4 Newsletter. (2013). Pariwisata Indonesia. Edisi 37 Januari. Direktorat Jenderal Pemasaran Pariwisata Kementerian Pariwisata dan Ekonomi Kreatif Republik Indonesia. 
Muslim berasal dari negara yang ekonominya sedang berkembang seperti Indonesia, Turki, dan Negara-negara Teluk. Oleh karena itu, Muslim merupakan konsumen penting dalam semua sektor bisnis, termasuk bisnis pariwisata. Dalam melakukan perjalanan, keyakinan (faith) turut memengarui wisatawan Muslim dalam memutuskan tempat wisata yang akan mereka tuju. Mereka tentu akan mencari dan membutuhkan produk-produk dan layanan-layanan yang sesuai dengan keyakinan mereka. Hal ini terlihat dengan semakin pesatnya pertumbuhan perbankan dan keuangan syariah, pangan halal (halal food), dan lain-lain di dunia.

Berdasarkan fakta tersebut maka Kementerian Pariwisata dan Ekonomi Kreatif telah menetapkan sedikitnya sembilan destinasi wisata yang saat ini mempunyai potensi untuk dipromosikan sebagai destinasi Wisata Syariah, yaitu Sumatera Barat, Riau, Lampung, Banten, Jakarta, Jawa Barat, Jawa Timur, Makasar, dan Lombok. Tahun 2016 Lombok menjadi pemenang dalam destinasi wisata syariah kelas dunia sebagai tempat wisata favorit untuk honeymoon.

Setelah berjalan beberapa tahun ide dari pariwisata syariah belum berkembang secara signifikan, salah satu hal yang menyebabkannya adalah belum adanya kajian mendalam mengenai landasan syariah yang kuat mengenai hal ini. Kontroversi di masyarakat mengenai istilah ini juga menjadi permasalahan tersendiri, misalnya beberapa daerah menolak gagasan ini karena dianggap sebagai sesuatu yang berbau Islami. Bali misalnya menolak ide pariwisata syariah karena dianggap sebagai upaya Islamisasi pariwisata di sana (www.balipedia.id). Mpu Jaya Prema salah seorang pendeta Hindu di Bali berpendapat bahwa upaya memunculkan ide pariwisata syariah karena hal ini menurutnya tidak patut kalau destinasi wisata dikaitkan dengan label agama.

Tentu saja pemikiran seperti ini muncul dari ketidakpahaman tentang konsep pariwisata syariah, sehingga yang muncul adalah islamopobhia. Hal ini tidak bisa dibiarkan, harus adanya edukasi dan sosialisasi agar gagasan pariwisata syariahn deng bisa diapahami dan diterima oleh semua umat manusia sebagaimana salah satu dari tujuan kehadiran Islam yaitu rahmatan lil'alamin.

Produk pariwisata akan dianggap sebagai pariwisata syariah apabila memenuhi kriteria yang telah diakui oleh 
Islam. Dalam hal ini produk tersebut selaras dengan nilai-nilai Islam, atau minimal tidak bertentangan dengan nilai-nilai Islam. Ukuran untuk menentukannya adalah melalui mekanisme fiqh Islam yang merujuk pada sumber dan dalil hukum Islam yaitu Al-Qur'an, Al-Hadits, Ijma', Qiyas, dan dalil hukum Islam lainnya.

Pada tataran lebih praktis maka ahli ushulfiqh telah merumuskan satu kaedah dalam menetapkan suatu produk harus sesuai dengan Islam dan selaras dengan tujuan syariat Islam (maqashid asySyariah). Sebagai satu teori yang dikembangkan oleh para fuqaha maka teori maqashid Syariah juga mengalami perkembangan dan disesuaikan dengan kebutuhan masyarakat muslim. Maka hal yang menarik adalah ketika konsep Pariwisata Syariah ditinjau dari perspektif maqashid syariah.

Membincang mengenai maqashid syariah maka tidak bisa melepaskan diri dari seorang tokoh yang menjadi hujjatul Islam yaitu Imam Al-Ghazali. Teori maqashid yang ditawarkan oleh beliau menjadi dasar bagi para pemikir setelahnya, termasuk tokoh-tokoh utama yang mengembangkan teori maqashid ini. Semisal Imam Asy-Syathibi, Ibnu Al-
Qayyim Al-Jauziyyah, Ibnu Taimiyah, serta tokoh-tokoh kontemporer dalam ranah maqashid syariah. Salah satu dari tokoh kontemporer yang fokus pada bidang ini adalah Imam Al-Jurjawi, seorang tokoh abad 19 M yang memberikan perhatian pada masalah ini. Beliau merumuskan mengenai maqashid syariah dengan lebih aplikatif. Kedua pemikir ini menarik dijadikan bahwa dalam menganalisis bagaimana eksistensi pariwisata syariah dalam Islam.

Berdasarkan latar belakang masalah, maka teridentifikasi beberapa permasalahan yang terkait dengan teori maqashid Syariah dalam menganalisis Pariwisata Syariah. Agar penelitian ini lebih mendalam maka akan terfokus pada pertanyaan-pertanyaan berikut ini:

1. Bagaimana eksistensi pariwisata syariah dalam Islam?

2. Bagaimana konsep pariwisata syariah dalam peraturan perundangundangan di Indonesia?

3. Bagaimana analisa teori-teori maqashid syariah menurut Imam Al-Ghazali dan Imam Al-Jurjawi mengenai pariwisata syariah?

Tujuan dari penelitian ini adalah untuk menjawab pertanyaan penelitian, yaitu: 
1. Menganalisis eksistensi pariwisata syariah dalam Islam

2. Menganalisa konsep pariwisata syariah dalam peraturan perundangundangan di Indonesia.

3. Menguraikan analisa teori-teori maqashid syariah mengenai pariwisata syariah khususnya menurut Imam Al-Ghazali dan Imam Al-Jurjawi.

\section{B. PEMBAHASAN}

\section{Pariwisata Syariah}

Pariwisata Syariah adalah "Suatu kegiatan wisata yang didukung dengan berbagai fasilitas serta layanan yang sesuai dengan prinsip Syariah". Adapun yang dimaksud dengan prinsip syariah adalah prinsip hukum Islam terkait berbagai kegiatan pariwisata berdasarkan fatwa yang dikeluarkan oleh lembaga yang berwenang. Di Indonesia lembaga dimaksud adalah Dewan Syariah Nasional Majelis Ulama Indonesia (DSN-MUI). "Pariwisata syariah dapat didefinisikan sebagai berbagai kegiatan wisata yang didukung berbagai fasilitas dan layanan yang disediakan masyarakat, pengusaha, pemerintah yang memenuhi ketentuan syariah.

Sebenarnya di dunia ada beberapa istilah yang menunjukkan pariwisata syariah. Misalkan di Malaysia menggunakan istilah Islamic tourism, di Uni Emirat Arab disebut sebagai family friendly tourism, sementara di Jepang halal tourism. Kementerian Pariwisata dan Ekonomi Kreatif menyebutnya dengan Pariwisata Syariah yaitu Pariwisata Syariah dengan wisata yang didasarkan pada nilainilai syariah Islam.

Pariwisata syariah merupakan suatu permintaan wisata yang didasarkan pada gaya hidup wisatawan muslim selama liburan. Selain itu, pariwisata syariah merupakan pariwisata yang fleksibel, rasional, sederhana dan seimbang. Pariwisata ini bertujuan agar wisatawan termotivasi untuk mendapatkan kebahagiaan dan berkat dari Allah.

Negara-negara Muslim cenderung menafsirkan pariwisata berdasarkan apa yang Al-Quran katakan. Berikut penjelasannya:

1. Hajja (حجة) melibatkan perjalanan dan ziarah ke Mekah. Perjalanan ini merupakan persyaratan untuk setiap Muslim dewasa yang sehat. Setidaknya sekali dalam seumur hidup untuk mengambil haji.

2. Ziyarah (زيارة) mengacu pada kunjungan ke tempat-tempat suci lainnya. 
3. Rihlah adalah perjalanan untuk alasan lain, seperti pendidikan dan perdagangan.

Berdasarkan karakteristik pariwisata syariah yang dijabarkan, terdapat empat aspek penting yang harus diperhatikan untuk menunjang suatu pariwisata syariah. ${ }^{5}$

a. Lokasi: Penerapan sistem Islami di area pariwisata. Lokasi pariwisata yang dipilih merupakan yang diperbolehkan kaidah Islam dan dapat meningkatkan nilai-nilai spiritual wisatawan.

b. Transportasi: Penerapan sistem, seperti pemisahan tempat duduk antara laki-laki dan wanita yang bukan mahram sehingga tetap berjalannya syariat Islam dan terjaganya kenyamanan wisatawan.

c. Konsumsi: Islam sangat memperhatikan segi kehalalan konsumsi, halal tersebut tertuang dalam Q.S. Al-Maidah Ayat 3. Segi kehalalan di sini baik dari sifatnya, perolehannya maupun pengolahannya. Selain itu, suatu

5 Chookaew, S., chanin, O., Charatarawat, J., Sriprasert, P., \& Nimpaya, S. (2015). Increasing Halal Tourism Potential at Andaman Gulf in. Journal of Economics, Business and Management, III (7). penelitian menunjukkan bahwa minat wisatawan dalam makanan memainkan peran sentral dalam memilih tujuan wisata.

d. Hotel: seluruh proses kerja dan fasilitas yang disediakan berjalan sesuai dengan prinsip syariah. Menurut Rosenberg, pelayanan di sini tidak sebatas dalam lingkup makanan maupun minuman, tetapi juga dalam fasilitas yang diberikan seperti spa, gym, kolam renang, ruang tamu dan fungsional untuk laki-laki dan perempuan sebaiknya terpisah.

Maqashid Syariah terdiri dari dua kata yaitu Maqashid dan Syari'ah. Maqashid berarti kesengajaan atau tujuan, kata ini merupakan bentuk jama' dari maqsud yang berasal dari suku kata qashada yang berarti menghendaki atau memaksudkan, Maqashid berarti hal-hal yang dikehendaki dan dimaksudkan. ${ }^{6}$

Sedangkan Syari'ah secara bahasa berarti المواضع تحدر الي الماءartinya “jalan menuju sumber air, yang juga diartikan berjalan menuju sumber kehidupan. Ibnu Mandzur mencatat bahwa syariah menurut bahasa adalah الوارد (al-warid) yang berarti

\footnotetext{
${ }^{6}$ Ibnu Mandzur. (1970). Lisaan Al-'Arab. juz 8, Beirut, Dar Lisan Al-Arab. hlm. 1119.
} 
jalan, dikatakan pula نحو الماء yaitu tempat keluarnya (mata) air. ${ }^{7}$ Al-Raghib menyatakan syariah adalah metode atau jalan yang jelas dan terang. Dikatakan: شرعت له نهجا (aku mensyariatkan padanya sebuah jalan), الثريعة al-syari'ah bisa pula bermakna sebuah tempat di tepi pantai.

Mannan' Khalil Al-Qathan berkata "Syariat pada asalnya menurut bahasa adalah sumber air yang digunakan untuk minum, kemudian digunakan oleh orangorang Arab dengan arti jalan yang lurus (alsyirath al-mustaqim) yang demikian itu karena tempat keluarnya air adalah sumber kehidupan dan keselamatan/kesehatan badan, demikian juga arah dari jalan yang lurus yang mengarahkankan manusia kepada kebaikan, padanya ada kehidupan jiwa dan pengoptimalan akal.

Maqashid Syariah adalah konsep untuk mengetahui hikmah (nilai-nilai dan sasaran syara' yang tersurat dan tersirat dalam AlQur'an dan Hadits) yang ditetapkan oleh alSyari' terhadap manusia adapun tujuan akhir hukum tersebut adalah satu, yaitu mashlahah atau kebaikan dan kesejahteraan umat manusia baik didunia (dengan mu'amalah) maupun di akhirat (dengan

\footnotetext{
${ }^{7}$ Ibnu Mandzur. (1970). Lisaan Al-'Arab. juz 8, Beirut, Dar Lisan Al-Arab. hlm. 86.
}

'aqidah dan ibadah). Sedangkancara untuk tercapai kemaslahatan tersebut manusia harus memenuhi kebutuhan dharuriat (Primer), dan menyempurnakan kebutuhan Hajiat (sekunder), dan Tahsiniat atau kamaliat (tersier).

Ibnu Qayyim menjelaskan bahwa Tujuan Hukum Islam adalah untuk mewujudkan kemashlahatan hamba dunia dan akhirat. Menurutnya, seluruh hukum itu mengandung keadilan, rahmat, kemashlahatan dan Hikmah, jika keluar dari keempat nilai yang dikandungnya, maka hukum tersebut tidak dapat dinamakan Hukum Islam. Hal senada juga dikemukakan oleh Imam Al-Syathibi, ia menegaskan bahwa semua kewajiban diciptakan dalam rangka merealisasikan kemashlahatan hamba. Tidak satupun hukum Allah yang tidak mempunyai tujuan. Hukum yang tidak mempunyai tujuan sama juga dengan taklif ma la yutaq' (membebankan sesuatu yang tidak dapat dilaksanakan).

Imam Al-Ghazali merumuskan adanya lima misi (Maqashid al-Syari'ah) atau yang disebut juga Maqashid al-Khamsah, yaitu memelihara Agama (hifdz dien), (nafs) Jiwa, ('aql) Aqal, (nasab) Keturunan dan (al-maal) Harta. Untuk mewujudkan dan memelihara kelima unsur pokok itu, Al- 
Syatibi membagi kepadatiga tingkat, مقاصد dan الضروريات مقاصد, حاجيات مقاصد . Pengelompokan ini didasarkan pada kebutuhan dan skala prioritas. Urutan level ini secara hirarkhis akan terlihat kepentingan dan siknifikansinya, manakala masing-masing level satu sama lain saling bertentangan. Dalam konteks ini level Dhururiyyat menempati peringkat pertama disusul Hajiyyat dan Tahsiniyyat. level Dhururiyat adalah memelihara kebutuhan yang bersifat esensial bagi kehidupan manusia. Bila kebutuhan ini tidak terpenuhi akan mengancam eksistensi kelima tujuan diatas. Sementara level Hajiyyat tidak mengancam hanya saja menimbulkan kesulitan bagi manusia. $^{8}$

Selanjutnya pada level Tahsiniyyat, adalah kebutuhan yang menunjang peningkatan martabat seseorang dalam masyarakat dan dihadapan Allah S.W.T. Sebagai contoh, dalam memelihara unsur Agama, aspek dhururiayyatnya antara lain mendirikan Shalat, shalat merupakan aspek dharuriayyat, keharusan menghadap kekiblat merupakan aspek hajiyyat, dan menutup aurat merupakan aspeks

${ }^{8}$ Abu Hamid Al-Gazali. (1993M/1413 H). AlMustashfa. tahqiq: Muhammad Abd Al-Salam Abd Al-Baqiy, Cet. I, Beirut: Dar al-Kutub al-'Ilmiyyah. hlm. 481 . tahsiniyyat. ${ }^{9}$ Ketiga level ini, pada hakikatnya adalah berupaya untuk memelihara kelima misi hukum Islam.

Maqashid Syariah atau tujuan syariah merujuk pada teori Al-Ghazali adalah sebagai berikut:

\section{Memelihara Agama (حفظ الدين)}

Menjaga atau memelihara agama, berdasarkan kepentingannya, dapat dibedakan menjadi tiga peringkat: Pertama, Memelihara Agama dalam peringkat Dharuriyyat, yaitu memelihara dan melaksanakan kewajiban keagamaan yang masuk peringkat primer, seperti melaksanakan Shalat lima waktu. Kalau shalat itu diabaikan maka akan terancamlah eksistensi Agama. Kedua, memelihara Agama dalam peringkat Hajiyyat, yaitu melaksanakan ketentuan Agama, dengan maksud menghindari kesulitan, seperti shalat jama' dan shalat qashar bagi orang yang sedang berpergian. Kalau ketentuan ini tidak dilaksanakan maka tidak akan mengancam eksistensi agama, melainkan hanya akan mempersulit bagi orang yang

${ }^{9}$ Abu Hamid Al-Gazali. (1993M/1413 H). AlMustashfa. tahqiq: Muhammad Abd Al-Salam Abd Al-Baqiy, Cet. I, Beirut: Dar al-Kutub al-'Ilmiyyah. hlm. 481 . 
melakukannya. Ketiga, Memelihara agama dalam peringkat tahsiniyyat, yaitu mengikuti petunjuk agama guna menjunjung tinggi martabat manusia sekaligus melengkapi pelaksanaan kewajiban terhadap tuhan.misalnya menutup aurat, baik di dalam maupun di luar shalat, membersihkan badan pakaian dan tempat, ketiga ini kerap kaitannya dengan Akhlak yang terpuji. Kalau hal ini tidak mungkin untuk dilakukan, maka hal ini tidak akan mengancam eksistensi agama dan tidak pula mempersulit bagi orang yang melakukannya.

\section{Memelihara jiwa (حفظ (النفس )}

Memelihara jiwa, berdasarkan tingkat kepentingannya, dapat dibedakan menjadi tiga peringkat: Pertama, memelihara jiwa dalam peringkat daruriyyat, seperti memenuhi kebutuhan pokok berupa makanan untuk mempertahankan hidup. Kalau kebutuhan pokok ini diabaikan, maka akan berakibat terancamnya eksistensi jiwa manusia. Kedua, memelihara jiwa, dalam peringkat hajiyyat, seperti diperbolehkan berburu binatang dan mencari ikan dilaut Belawan untuk menikmati makanan yang lezat dan halal, kalau kegiatan ini diabaikan, maka tidak akan mengancam eksistensi manusia, melainkan hanya mempersulit hidupnya. Ketiga, memelihara dalam tingkat tahsiniyyat, seperti ditetapkannya tatacara makan dan minum, kegiatan ini hanya berhubungan dengan kesopanan dan etika, sama sekali tidak akan mengancam eksistensi jiwa manusia, ataupun mempersulit kehidupan seseorang.

\section{Memelihara Aqal (حفظ (لعقل )}

Memelihara aqal, dilihat dari segi kepentingannya, dapat dibedakan menjadi tiga peringkat: Pertama, Memelihara aqal dalam peringkat daruriyyat, seperti diharamkan meminum minuman keras. Jika ketentuan ini tidak diindahkan, maka akan berakibat terancamnya eksistensi akal. Kedua, Memelihara aqal dalam peringkat hajiyyat, seperti dianjurkannya menurut Ilmu pengetahuan. Sekiranya hal itu dilakukan, maka tidak akan merusak aqal, tetapi akan mempersulit diri seseorang, dalam kaitannya dengan pengembangan ilmu pengetahuan. Ketiga, Memelihara aqal dalam peringkat tahsiniyyat. Seperti menghindarkan diri dari menghayal atau mendengarkan sesuatu yang tidak berfaedah. Hal ini erat kaitannya dengan etika, tidak akan mengancam eksistensi aqal secara langsung.

\section{Memelihara keturunan (حفظ النسل)}

Memelihara keturunan, ditinjau dari segi tingkat kebutuhannya, dapat dibedakan menjadi tiga peringkat: Pertama, 
memelihara keturunan dalam peringkat dhururiyyat, seperti disyari'atkan nikah dan dilarang berzina. Kalau kegiatan ini diabaikan, maka eksistensi keturunan akan terancam. Kedua, memelihara keturunan dalam peringkat hajiyyat, seperti ditetapkannya ketentuan menyebutkan mahar bagi suami pada waktu akad nikah dan diberikan hak talak padanya. Jika mahar itu tidak disebutkan pada waktu aqad, maka suami akan mengalami kesulitan, karena ia harus membayar mahar misl, sedangkan dalam kasus talak, suami akan mengalami kesulitan, jika ia tidak menggunakan hak talaknya, padahal situasi rumah tangganya tidak harmonis. Ketiga, memelihara keturunan dalam peringkat tahsiniyyat, seperti disyari'tkan khitbah atau walimah dalam perkawinan. Hal ini dilakukan dalam rangka melengkapi kegiatan perkawinan. Jika hal ini diabaikan, maka tidak akan mengancam eksistensi keturunan, dan tidak pula mempersulit orang yang melakukan perkawinan.

\section{Memelihara Harta (حفظ المال)}

Dilihat dari segi kepentingannya, Memelihara harta dapat dibedakan menjadi tiga peringkat: Pertama, memelihara harta dalam peringkat dhururiyyat, seperti syari'at tentang tatacara pemilikan harta dan larangan mengambil harta orang lain dengan cara yang tidak sah, apabila aturan itu dilanggar, maka berakibat terancamnya eksistensi harta. Kedua, memelihara harta dalam peringkat hajiyyat seperti syari'at tentang jual beli dengan cara salam. Apabila cara ini tidak dipakai, maka tidak akan terancam eksistensi harta, melainkan akan mempersulit orang yang memerlukan modal. Ketiga, memelihara harta dalam peringkat tahsiniyyat, seperti ketentuan tentang menghindarkan diri dari pengecohan atau penipuan. Hal ini erat kaitannya dengan etika bermuamalah atau etika bisnis. Hal ini juga akan mempengaruh kepada sah tidaknya jual beli itu, sebab peringkat yang ketiga ini juga merupakan syarat adanya peringkat yang kedua dan pertama.

Berdasarkan pembahasan ini maka dapat dipahami bahwa tujuan atau hikmah pensyari'atan hukum Islam adalah untuk mewujudkan kemaslahatan melalui pemeliharaan lima unsur pokok, yaitu agama, jiwa, akal, keturunan dan harta. Apabila kelima hal ini diabaikan, maka sama saja dengan tidak memperhatikan tujuan utama adanya syariat dalam Islam.

Pariwisata Syariah: Analisa Maqashid Syariah Menurut Imam AlGhazali dan Imam Al-Jurjawi 
Wisata sebagai salah satu kebutuhan manusia telah diatur dalam syariat Islam, sehingga dalam pelaksanaanya haruslah didasarkan pada nilai-nilai Islam. Tujuan syariat Islam atau yang dikenal dengan istilah maqashid syariah memberikan panduan bagi umat Islam dalam melaksanakan pariwisata syariah ini. Ia juga menjadi pedoman dalam mengembangkannya. Beberapa tokoh yang merumuskan teori maqashid syariah di antaranya adalah Imam Al-Ghazali dan Imam Al-Jurjawi, keduanya sangat memperhatikan bagaimana Islam sangat memperhatikan kebutuhan manusia dan apa yang bermanfaat untuk mereka.

Manusia membutuhkan suasana baru yang akan menyegarkan jiwa dan raganya, suasana yang berbeda dengan keadaan sehari-harinya yang menjadikannya kembali bersemangat dalam melakukan aktifitas. Wisata saat ini tidak hanya menjadi kebutuhan sekunder namun menjadi kebutuhan primer pada beberapa kalangan. Sementara para praktisi pariwisata syariah menjadikannya sebagai profesi utama.

Wisata dalam Islam dipahami sebagai bepergian untuk mendapatkan satu kesegaran baru dalam suasana yang berbeda. Negara-negara Muslim cenderung menafsirkan pariwisata berdasarkan apa yang Al-Qur'an katakan. Pariwisata syariah merupakan pariwisata yang mengendepankan nilai-nilai Islami dalam setiap aktvitasnya. Namun, istilah pariwisata syariah secara definisi di kalangan pelaku wisata masih cenderung asing.

Pariwisata syariah lebih dimaknai sebagai wisata reliji, yaitu kunjungankunjungan ke tempat ibadah untuk berziarah atau tempat-tempat ibadah lainnya. Padahal, pariwisata syariah tidak terfokus pada objek saja, tetapi adab perjalanan dan fasilitas lainnya. ${ }^{10}$ Objek pariwisata syariah pun tidak harus objek yang bernuansa Islam, seperti masjid dan peninggalan sejarah Islam. Objek pariwisata syariah berlaku untuk semua tempat, kecuali tempat ibadah agama lain. Pariwisata syariah memberikan makna kepada masyarakat bahwa masyarakat muslim harus ber-Islam dimanapun dan kapan pun.

Pemaknaan yang kurang tepat terkait pariwasata syariah ini disebabkan karena edukasi yang kurang. Dari sudut pandang

${ }^{10}$ Chookaew, S., chanin, O., Charatarawat, J., Sriprasert, P., \& Nimpaya, S. (2015). Increasing Halal Tourism Potential at Andaman Gulf in. Journal of Economics, Business and Management, III (7). 
wisatawan, ketersediaan informasi yang kurang adalah penyebab utama ketidakpahaman tentang pariwisata syariah. Hal ini sesuai dengan hasil kuesioner, yaitu 79\% responden merasa kurang mendapat informasi mengenai pariwisata syariah. Dari sudut pandang pelaku bisnis, pariwisata syariah belum begitu dikenal jelas karena belum adanya panduanpanduan jelas terkait pariwisata syariah. Pemerintah daerah pun belum berani mengembangkan pariwisata syariah karena belum ada panduan dan arahan yang jelas dari pemerintah pusat terkait pengembangan pariwisata syariah walaupun pemerintah daerah sudah paham secara umum terkait pariwsisata syariah.

Berikut bentuk pariwisata berdasarkan Al-Qur'an:

1. Hijja (melibatkan perjalanan dan ziarah ke Mekah. Perjalanan ini merupakan persyaratan untuk setiap Muslim dewasa yang sehat. Setidaknya sekali dalam seumur hidup untuk mengambil haji.

2. Zejara (زيراة) mengacu pada kunjungan ke tempat-tempat suci lainnya.

3. Rihla (رحلة) adalah perjalanan untuk alasan lain, seperti pendidikan dan perdagangan.
Merujuk pada beberapa istilah tersebut, maka wisata dalam Islam sejatinya adalah satu aktifitas yang direncanakan dalam rangka menyegarkan kembali akal, pikiran dan tubuh manusia dengan tetap menjadikannya sebagai ibadah kepada Allah Ta'ala. Shari'ahhukum menentukan apa yang dapat diterima halal dan apa yang tidak diterima haram dalam kehidupan sehari-hari dan selama perjalanan. Artinya bahwa, walaupun wisata ini selah-olah hanya berfungsi secara duniawi saja, namun ia juga harus tetap selaras dengan nilai-nilai syariah.

Menurut Chookaew, terdapat delapan faktor standar pengukuran pariwisata syariah dari segi administrasi dan pengelolaannya untuk semua wisatawan yang halal tersebut dapat menjadi suatu karakteristik tersendiri, yaitu: ${ }^{11}$

1. Pelayanan kepada wisatawan harus cocok dengan prinsip muslim secara keseluruhan;

2. Pemandu dan staf harus memiliki disiplin dan menghormati prinsipprinsip Islam;

${ }^{11}$ Chookaew, S., chanin, O., Charatarawat, J., Sriprasert, P., \& Nimpaya, S. (2015). Increasing Halal Tourism Potential at Andaman Gulf in. Journal of Economics, Business and Management, III (7). 
3. Mengatur semua kegiatan agar tidak bertentangan dengan prinsip Islam;

4. Bangunan harus sesuai dengan prinsip-prinsip Islam;

5. Restoran harus mengikuti standar internasional pelayanan halal;

6. Layanan transportasi harus memiliki keamanan sistem proteksi;

7. Ada tempat-tempat yang disediakan untuk semua wisatawan muslim melakukan kegiatan keagamaan; dan

8. Bepergian ke tempat-tempat yang tidak bertentangan dengan prinsip Islam.

Berdasarkan karakteristik pariwisata syariah yang dijabarkan, terdapat empat aspek penting yang harus diperhatikan untuk menunjang suatu pariwisata syariah. $^{12}$

1. Lokasi: Penerapan sistem Islami di area pariwisata. Lokasi pariwisata yang dipilih merupakan yang diperbolehkan kaidah Islam dan dapat meningkatkan nilai-nilai spiritual wisatawan.

${ }^{12}$ Chookaew, S., chanin, O., Charatarawat, J., Sriprasert, P., \& Nimpaya, S. (2015). Increasing Halal Tourism Potential at Andaman Gulf in. Journal of Economics, Business and Management, III (7).
2. Transportasi: Penerapan sistem, seperti pemisahan tempat duduk antara laki-laki dan wanita yang bukan mahram sehingga tetap berjalannya syariat Islam dan terjaganya kenyamanan wisatawan.

3. Konsumsi: Islam sangat memperhatikan segi kehalalan konsumsi, hal tersebut tertuang dalam Q.S. Al-Maidah Ayat 3. Segi kehalalan disini baik dari dari sifatnya, perolehannya maupun pengolahannya. Selain itu, suatu penelitian menunjukkan bahwa minat wisatawan dalam makanan memainkan peran sentral dalam memilih tujuan wisata.

4. Hotel: seluruh proses kerja dan fasilitas yang disediakan berjalan sesuai dengan prinsip syariah. Menurut Rosenberg, pelayanan disini tidak sebatas dalam lingkup makanan maupun minuman, tetapi juga dalam fasilitas yang diberikan seperti spa, gym, kolam renang, ruang tamu dan fungsional untuk laki-laki dan perempuan sebaiknya terpisah.

Merujuk pada konsep tersebut, berikut adalah bagan perbedaan mendasarkan antara model pariwisata syariah dan non syariah: 


\begin{tabular}{|c|c|c|c|}
\hline No & Unsur Wisata Syariah & Syariah & Non Syariah \\
\hline 1 & Lokasi & $\begin{array}{lrr}\text { Lokasi pariwisata } & \text { yang } \\
\text { dipilih merupakan yang } & \text { yan } \\
\text { diperbolehkan } & \text { kaidah } \\
\text { Islam dan dapat } \\
\text { meningkatkan nilai-nilai } \\
\text { spiritual wisatawan. }\end{array}$ & $\begin{array}{l}\text { Tidak ada aturan, mereka } \\
\text { hanya fokus pada lokasi } \\
\text { yang strategis. }\end{array}$ \\
\hline 2 & Transportasi & $\begin{array}{l}\text { Tempat duduk antara laki- } \\
\text { laki dan wanita yang } \\
\text { bukan mahram terpisah } \\
\text { agar tetap berjalannya } \\
\text { syariat Islam dan } \\
\text { terjaganya kenyamanan } \\
\text { wisatawan (Utomo, 2014). }\end{array}$ & $\begin{array}{l}\text { Tidak ada aturan, mereka } \\
\text { hanya membahas tentang } \\
\text { kenyamanan transportasi. }\end{array}$ \\
\hline 3 & Konsumsi & $\begin{array}{l}\text { Kehalalandari dari sifat, } \\
\text { perolehannya dan tata cara } \\
\text { pengolahannya. Q.S. Al- } \\
\text { Maidah Ayat 3. }\end{array}$ & $\begin{array}{l}\text { Tidak ada aturan halal atau } \\
\text { haram. }\end{array}$ \\
\hline 4 & Hotel & $\begin{array}{l}\text { Seluruhproses kerja dan } \\
\text { fasilitas yang disediakan } \\
\text { berjalan sesuai dengan } \\
\text { prinsip syariah: makanan } \\
\text { maupun minuman, spa, } \\
\text { gym, kolam renang, ruang } \\
\text { tamu dan fungsional untuk } \\
\text { laki-laki dan perempuan } \\
\text { sebaiknya terpisah. }\end{array}$ & $\begin{array}{l}\text { Tidak ada aturan, mereka } \\
\text { hanya bicara tentang } \\
\text { layanan prima (exeellent) } \\
\text { dengan prinsip pengguna } \\
\text { adalah raja. }\end{array}$ \\
\hline
\end{tabular}

Merujuk kepada beberapa pendapat mengenai eksistensi pariwisata syariah maka pada dasarnya ia merupakan kebutuhan umat, sehingga hukum asalnya adalah mubah (boleh). Hal ini didasarkan kepada ayat-ayat Al-Qur'an mengenai perintah untuk berjalan di muka bumi.

Pariwisata Syariah sebagai term baru dalam ranah pariwisata di Indonesia muncul sebagai efek dari kesadaran umat Islam akan layanan pariwisata yang didasarkan kepada nilai-nilai kepercayaan masyarakat di Indonesia yaitu Islam. Perkembangan ekonomi Islam yang terus berjalan merambah ke bidang Islamic tourisme atau pariwisata syariah.

Peluang dari pengembangan wisata syari'ah (islami) yaitu potensi pasar baik wisatawan domestik (penduduk Indonesia 90\% beragama Islam) maupun 
mancanegara (khusus Timur Tengah dan Malaysia cukup menjanjikan). Potensi yang menjanjikan terhadap pengembangan wisata islami atau wisata syariah di Indonesia semakin diperkuat dengan launching pariwisata syari'ah pada tanggal 30 Oktober 2013 pada acara Indonesia Halal Expo (INDEX) di Jakarta Internasional Expo yang didukung oleh Kementrian Pariwisata dan Ekonomi Kreatif (Kemenparekraf) dan Majelis Ulama Indonesia.

Peraturan perundang-undangan yang berkaitan dengan pariwisata syariah adalah:

1. Peraturan Menteri Pariwisata Republik Indonesia Nomor 1 Tahun 2016 Tentang Penyelenggaraan Sertifikasi Usaha Pariwisata.

2. Peraturan Menteri Pariwisata dan Ekonomi Kreatif Indonesia No. 2 Tahun 2014 tentang Pedoman Penyelenggaraan Usaha Hotel Syariah.

3. Peraturan Gubernur Nusa Tenggara Barat No 51 Tahun 2015 Tentang Wisata Halal.

Majelis Ulama Indonesia (MUI) mendorong pemerintah untuk membentuk Undang-Undang Pariwisata Syariah sebagai dasar hukum pengaturan dan pengembangan pariwisata di Tanah Air.
Masukan tersebut dikeluarkan MUI setelah melalui Ijtima Ulama Komisi Fatwa seIndonesia V Tahun 2015, Komisi B2 Masail Fiqhiyyah Muashirah (masalah fikih kontemporer) tentang usul pembentukan perundang-undangan. Menurut MUI, penerbitan aturan itu agar perkembangan wisata di Tanah Air tetap menjaga nilainilai dan ajaran agama.

Selain itu, mencegah terjadinya kerusakan dan kerugian akibat pariwisata." MUI mendorong pemerintah segera membentuk berbagai regulasi/ketentuan perundang-undangan di bidang hotel syariah, traveling syariah, dan entertainment syariah". Hal itu, untuk meningkatkan peran dan sumbangsih ekonomi syariah dalam menggerakkan perekonomian nasional serta pendapatan negara dan masyarakat sekaligus memperbanyak sektor aktivitas perekonomian syariah.

Adapun MUI menyebutkan beberapa hal yang harus diperhatikan dalam pembentukan peraturan pariwisata syariah, seperti berorientasi pada kemaslahatan umum; berorientasi pada pencerahan, penyegaran, dan ketenangan; menghindari kemusyrikan dan khurafat; menghindari maksiat, seperti zina, pornografi, pornoaksi, 
prostitusi, minuman keras, narkoba, dan judi.

Hal lain yang diperhatikan, yakni menjaga perilaku, etika, dan nilai luhur kemanusiaan seperti menghindari perilaku hedonis dan asusila; menjaga amanah, keamanan, dan kenyamanan; bersifat universal dan inklusif; menjaga kelestarian lingkungan; terakhir, menghormati nilainilai luhur sosial budaya dan kearifan lokal.

\section{Analisa Teori-Teori Maqashid Syariah Mengenai Pariwisata Syariah}

Analisa maqashid syariah yang digunakan dalam penelitian ini merujuk pada teori maqashid yang dijelaskan oleh Imam Al-Ghazali. Beliau membagi Maqashid al-syari'ah menjaditiga; pertama, al-dharurat (hak primer); kedua, al-hajat (hak skunder); dan ketiga al-tazzayunat wa al-tashilat atau al-tahsinat (hak suplementer). Jika konsep ini diterapkan dalam wisata syariah maka sebagai berikut:

\begin{tabular}{|c|l|c|c|c|}
\hline No & Unsur Wisata Syariah & Al-Dharurat & Al-Hajat & Al-Tahsinat \\
\hline $\mathbf{1}$ & Produk & & $\mathrm{v}$ & \\
\hline $\mathbf{2}$ & Pelayanan & & $\mathrm{v}$ & \\
\hline $\mathbf{3}$ & Pengelolaan & & $\mathrm{v}$ & \\
\hline
\end{tabular}

Produk dalam wisata syariah masuk ke dalam kebutuhan yang sifatnya al-hajat, ia adalah pelengkap bagi kebutuhan manusia yang bersifat al-dharurat. Walaupun ia bersifat sekunder namun menjadi hal yang banyak dilakukan oleh umat Islam sehingga haruslah tetap diselaraskan dengan nilainilai Islam dalam pelaksanaannya.

Unsur-unsur pariwisata syariah berdasarkan analisis maqashid asy-syariah adalah sebagai berikut:

\begin{tabular}{|c|l|c|c|c|c|c|}
\hline No & \multicolumn{1}{|c|}{ Unsur Wisata Syariah } & $\begin{array}{c}\text { Hifdz } \\
\text { al-Din }\end{array}$ & $\begin{array}{c}\text { Hifdz } \\
\text { al-Nafs }\end{array}$ & $\begin{array}{c}\text { Hifdz } \\
\text { al-‘Aql }\end{array}$ & $\begin{array}{c}\text { Hifdz } \\
\text { An-Nasl }\end{array}$ & $\begin{array}{c}\text { Hifdz al- } \\
\text { Maal }\end{array}$ \\
\hline $\mathbf{1}$ & Produk & $\mathrm{v}$ & & $\mathrm{v}$ & & $\mathrm{v}$ \\
\hline $\mathbf{2}$ & Pelayanan & & & $\mathrm{v}$ & & $\mathrm{v}$ \\
\hline $\mathbf{3}$ & Pengelolaan & & & & & $\mathrm{v}$ \\
\hline
\end{tabular}


Berdasarkan matrik ini dapat disimpulkan bahwa konsep wisata syariah berdasarkan produknya masuk ke dalam hifdz din, hifdz al'aql dan hifdz al-mal. Produk wisata syariah dalam bentuk makanan, minuman dan jasa sejatinya adalah upaya untuk melindungi agama seseorang. Demikian juga ia melindungi akal dan harta manusia, karena jika ini tidak diperhatikan maka produk yang ada tidak memperhatikan akal manusia misalnya berbagai minuman yang akan merusak akal manusia. Jika produk tersebut ternyata merupakan bentuk pemborosan maka tidak sesuai dengan hifdz al-mal perlindungan terhadap harta.

Pelayanan pariwisata syariah hendaknya didasarkan pada perlindungan terhadap harta. Hifdz al-malyang dimaksud adalah melindungi siapa saja yang menikmati layanan tersebut agar tidak saling memakan harta secara batil seperti dalam hal perjudian, gharar, najasy dan akad yang diharamkan lainnya.

Pengelolaan dalam pariwisata syariah didasarkan pula pada hifdz al-malyaitu perlindungan terhadap harta. Praktisi pariwisata syariah hendaknya menjadikan model pengelolaan harta secara islami dalam pelaksanaan pengelolaan jasa pariwisatanya. Sehingga harta yang ada padanya akan dilindungi secara syar'i.

Analisis maqashid syariah menurut Imam Al-Jurjawi didasarkan pada tujuan dari maqashid syariah yaitu;

1. Mengenal Allah, mengesakan, memuji dan mengenal sifat-sifatNya yang sempurna, baik sifat wajib, sifat mustahil dan sifat jaiz.

2. Cara melaksanakan ibadah kepadaNya dalam rangka mengagungkan dan mensyukuri nikmatNya yang tak terhingga

3. Memotivasi untuk amar ma'ruf nahi mungkar, dan menghiasi diri dengan akhlak mulia

4. Menghentikan penyelewengan dengan melaksanakan hukum yang ditetapkan dalam bermuamalah, di mana sistem sosial dan keamanan akan menjadi rusak bila hukuman tersebut tidak dijalankan.

Merujuk pada konsep ini maka, pariwisata syariah haruslah didasarkan pada tujuan syariah tersebut. Berikut ini adalah hasil analisisnya:

\begin{tabular}{|c|l|l|l|l|}
\hline No & \multicolumn{1}{|c|}{ Tujuan Syariah Al-Jurjawi } & \multicolumn{1}{|c|}{ Produk } & Pelayanan & Pengelolaan \\
\hline 1 & Mengenal Allah, mengesakan, & Produk & Pelayanan & Pengelolaan \\
\hline
\end{tabular}




\begin{tabular}{|c|c|c|c|c|}
\hline & $\begin{array}{l}\text { memuji dan mengenal sifat- } \\
\text { sifatNya yang sempurna, baik sifat } \\
\text { wajib, sifat mustahil dan sifat jaiz }\end{array}$ & $\begin{array}{l}\text { wisata yang } \\
\text { ada harus } \\
\text { menjadi } \\
\text { sarana } \\
\text { mengenal } \\
\text { Allah Ta'ala }\end{array}$ & $\begin{array}{l}\text { harus } \\
\text { didasarkan } \\
\text { pada } \\
\text { pengenalan } \\
\text { kepada Allah } \\
\text { Ta'ala }\end{array}$ & $\begin{array}{l}\text { harus menjadi } \\
\text { sarana dalam } \\
\text { mengenal } \\
\text { Allah Ta'ala }\end{array}$ \\
\hline 2 & $\begin{array}{l}\text { Cara melaksanakan ibadah } \\
\text { kepadaNya dalam rangka } \\
\text { mengagungkan dan mensyukuri } \\
\text { nikmatNya yang tak terhingga }\end{array}$ & $\begin{array}{l}\text { Produk yang } \\
\text { ada tidak } \\
\text { meninggalkan } \\
\text { ibadah }\end{array}$ & $\begin{array}{l}\text { Pelayanan yang } \\
\text { ada harus } \\
\text { memberikan } \\
\text { sarana untuk } \\
\text { beribadah }\end{array}$ & $\begin{array}{l}\text { Pengelolaan } \\
\text { yang ada harus } \\
\text { memudahkan } \\
\text { dalam } \\
\text { beribadah }\end{array}$ \\
\hline 3 & $\begin{array}{l}\text { Memotivasi untuk amar ma'ruf } \\
\text { nahi mungkar, dan menghiasi diri } \\
\text { dengan akhlak mulia }\end{array}$ & $\begin{array}{l}\text { Produk yang } \\
\text { ada menjadi } \\
\text { sarana dalam } \\
\text { amar ma'ruf } \\
\text { nahi munkar }\end{array}$ & $\begin{array}{l}\text { Pelayanan ini } \\
\text { yang } \\
\text { didasarkan } \\
\text { pada semangat } \\
\text { amar ma'ruf } \\
\text { nahi munkar }\end{array}$ & $\begin{array}{l}\text { Pengelolaan } \\
\text { harus } \\
\text { didasarkan } \\
\text { pada semangat } \\
\text { amar ma'ruf } \\
\text { nahi munkar }\end{array}$ \\
\hline 4 & $\begin{array}{l}\text { Menghentikan penyelewengan } \\
\text { dengan melaksanakan hukum yang } \\
\text { ditetapkan dalam bermuamalah. }\end{array}$ & $\begin{array}{l}\text { Produk yang } \\
\text { ada tidak } \\
\text { menghalangi } \\
\text { pelaksanaan } \\
\text { hukum Islam }\end{array}$ & $\begin{array}{l}\text { Pelayanan } \\
\text { harus mampu } \\
\text { menghentikan } \\
\text { hal-hal yang } \\
\text { bertentangan } \\
\text { dengan hukum } \\
\text { Islam }\end{array}$ & $\begin{array}{l}\text { Pengelolaan } \\
\text { yang ada harus } \\
\text { mampu } \\
\text { menghentikan } \\
\text { hal-hal yang } \\
\text { bertentangan } \\
\text { dengan hukum } \\
\text { Islam } \\
\end{array}$ \\
\hline
\end{tabular}

Berdasarkan analisis ini maka dapat disimpulkan bahwa tujuan syariah atau maqashid syariah dalam pandangan merujuk pada empat komponen tersebut, yaitu:

1. Mengenal Allah, mengesakan, memuji dan mengenal sifat-sifatNya yang sempurna, baik sifat wajib, sifat mustahil dan sifat jaiz. Konsep ini mengharuskan produk wisata yang ada harus menjadi sarana mengenal Allah Ta'ala. Sementara Pelayanan harus didasarkan pada pengenalan kepada Allah Ta'ala. Adapun pengelolaan harus menjadi sarana dalam mengenal Allah Ta'ala

2. Cara melaksanakan ibadah kepadaNya dalam rangka mengagungkan dan mensyukuri nikmatNya yang tak terhingga. Maka produk yang ada tidak meninggalkan ibadah. Pelayanan yang ada harus memberikan sarana untuk beribadah dan Pengelolaan 
yang ada harus memudahkan dalam beribadah.

3. Memotivasi untuk amar ma'ruf nahi mungkar, dan menghiasi diri dengan akhlak mulia. Produk yang ada menjadi sarana dalam amar ma'ruf nahi munkar. Pelayanan ini yang didasarkan pada semangat amar ma'ruf nahi munkar. Pengelolaan harus didasarkan pada semangat amar ma'ruf nahi munkar.

4. Menghentikan penyelewengan dengan melaksanakan hukum yang ditetapkan dalam bermuamalah. Produk yang ada tidak menghalangi pelaksanaan hukum Islam. Pelayanan harus mampu menghentikan hal-hal yang bertentangan dengan hukum Islam. Pengelolaan yang ada harus mampu menghentikan hal-hal yang bertentangan dengan hukum Islam

\section{KESIMPULAN}

Merujuk kepada pembahasan mengenai analisa pariwisata syariah dengan menggunakan maqashid syariah menurut Imam Al-Ghazali dan Imam Al-Jurjawi maka dapat disimpulkan beberapa hal sebagai berikut:
1. Pariwisata dalam Islam merupakan kebutuhan al-hajiyaat (sekunder), sehingga ia harus didasarkan pada nilai-nilai syariah. Hukumnya sendiri mubah (boleh) untuk dilaksanakan dengan tetap menjaga nilai-nilai syariah dalam pelaksanaannya.

2. Konsep pariwisata syariah dalam peraturan perundang-undangan di Indonesia debatable. Masih belum ada dukungan secara optimal dari pemerintah pusat, sehingga perkembangannya terkesan lambat. Beberapa wilayah yang dijadikan tujuan destinasi wisata syariah mengembangkan sendiri peraturan daerah mengenai wisata syariah misalnya Aceh dan Lombok.

3. Pariwisata Syariah dalam perspektif maqashid asy-syariah menurut Imam Al-Ghazali dan Imam AlJurjawi sebagai berikut: Wisata Syariah merupakan kebutuhan alhajiyaat sekunder bagi umat Islam. Sehingga dalam pelaksanaannya harus didasarkan pada nilai-nilai Syariah yang telah ditentukan dalam Islam. Analisis maqashid Imam AlGhazali menunjukan bahwa pelaksanaannya harus 
memperhatikan; hifdz ad-din, hifdz al-'aql, hifdz an-Nafs, hifdz al-nasb dan hifdz al-maal. Analisis Maqashid Al-Jurjawi menunjukan bahwa pariwisata syariah; mengenal Allah, sarna ibadah, amar ma'ruf nahi munkar dan tidak menghalangi pelaksanaan hukum Islam.

Beberapa rekomendasi dari penelitian ini adalah bahwa hendaknya para pengelola wisata syariah berusaha untuk senantiasa komitmen dengan aturan-aturan syariah. Demikian pula dalam hal layanan dan produk-produknya. Pengelolaannya sendiri harus didasarkan kepada pengelolaan harta secara islami sehingga akan terbebas dari segala bentuk transaksi yang diharamkan dalam Islam.
Al-Salam Abd Al-Baqiy, Cet. I, Beirut: Dar al-Kutub al-'Ilmiyyah.

Chookaew, S., chanin, O., Charatarawat, J., Sriprasert, P., \& Nimpaya, S. (2015). Increasing Halal Tourism Potential at Andaman Gulf in. Journal of Economics, Business and Management, III (7).

Mandzur, Ibnu. (1970). Lisaan Al-'Arab. juz 8, Beirut, Dar Lisan Al-Arab.

Newsletter "Pariwisata Indonesia" Edisi 37 Januari. (2013). Direktorat Jenderal Pemasaran Pariwisata Kementerian Pariwisata dan Ekonomi Kreatif Republik Indonesia.

http://bps.go.id/download_file/Penduduk_in donesia_menurut_desa_SP2010.pdf

http://www.budpar.go.id/asp/detil.asp?c=16 $\& \mathrm{id}=2042$.

Kementerian Pariwisata dan Ekonomi Kreatif. Undang-Undang Republik Indonesia No. 10 Tahun 2009 tentang Kepariwisataan.

\section{DAFTAR PUSTAKA}

Al-Gazali, Abu Hamid. (1993M/1413 H). Al-Mustashfa. tahqiq: Muhammad Abd 